\title{
The Supernatural and the Real: Dreams, Myths, and Perceptions of Reality in Ben Okri's The Famished Road
}

\author{
Doğaüstü ve Gerçek: Ben Okri'nin Aç Yol Adlı Romanında Rüyalar, Efsaneler \\ ve Gerçeklik Algılart
}

\section{Aslı DEĞİRMENCİ*}

\begin{abstract}
The supernatural content of Ben Okri's novel The Famished Road spreads through the narrative and also affects the formal structure of the novel. The fact that narrator of the novel, Azaro is an abiku (spirit child) provides the basis for all of the supernatural phenomena in the novel. Furthermore, the Yoruba myth of abiku lends its cyclicality to the narrative structure. Many transitions occuring as Nigeria gets closer to independence are depicted through the eyes of Azaro, who, as a small child from a povertystricken working class family, travels many roads around his ghetto, registering all the developments that transform his environment irretrievably. This article suggests that Okri's use of a culturally specific supernatural phenomenon (abiku) at the center of his narrative as well as the lack of references to a colonial presence provides him with the ability to depict a single inherently supernatural reality while at the same time depicting the transformation of colonial Nigeria, particularly the environmental changes, quite realistically.
\end{abstract}

Keywords: Ben Okri, The Famished Road, Magical Realism, Nigeria, Abiku, Supernatural, Postcolonial Novel.

$\ddot{O}_{z}$ : Ben Okri'nin $A_{c ̧} Y o l$ adlı romanın doğaüstü içeriği anlatının her tarafına yayılıp romanın biçimsel yapısını da etkilemektedir. Romanın anlatııısı Azaro'nun bir "abiku" (peri-çocuk) olması romandaki bütün doğaüstü olaylar için bir zemin sağlamaktadır. Dahası, bir Yoruba efsanesi olan "abiku" döngüselliğini romanın öykü yapısına da verir. Nijerya'nın bağımsızlığı yaklaşırken gerçekleşen bir çok olay, oldukça fakir bir işçi sınıfi ailesinin çocuğu olarak mahallesindeki yolları arşınlayan ve çevresini geri dönüşü olmayacak şekilde dönüştüren gelişmeleri kaydeden Azaro'nun gözünden aktarılır. Bu makale, kültürel olarak belirgin bir doğaüstü olayı (“abiku”yu) anlatısının merkezine oturtmasının ve aynı zamanda sömürge döneminin varlı̆̆ına ait göndermelerin olmamasının Ben Okri'ye kendiliğinden doğaüstü olan münferit bir gerçekliği resmetme firsatı verdiğini, hem de bunu sömürge dönemi Nijerya'sındaki dönüşümü, özellikle de çevresel değişimleri oldukça gerçekçi bir şekilde anlatarak yaptığını öne sürmektedir.

Anahtar sözcükler: Ben Okri, Aç Yol, Büyülü Gerçekçilik, Nijerya, Abiku, Doğaüstü, Sömürge Dönemi Sonrası Roman.

Ben Okri is one of the most acclaimed writers of contemporary Nigerian literature. Born in central Nigeria in 1959, Okri spent the first ten years of his life in London and returned to Nigeria in 1969 and lived in Lagos when the country was politically unstable due to the Nigerian Civil War that lasted from 1967 to 1970. Okri left for England a second time in 1978

\footnotetext{
* Dr., Hacettepe Üniversitesi, Edebiyat Fakültesi, İngiliz Dili ve Edebiyatı Bölümü, Ankara. aslidegirmenci01@gmail.com
} 
to study comparative literature at the University of Essex. After his graduation, Okri has written critically acclaimed poetry, short stories, and novels that focus on the experiences of contemporary Nigeria (Wilkinson 1992, 76). His novel Incidents at the Shrine won the 1987 Commonwealth Writers Prize (Africa Region); his short story collection Stars of the New Curfew was shortlisted for the Guardian Fiction Prize in 1988, and The Famished Road (1991) won the 1991 Booker Prize. Okri later published two sequels to The Famished Road turning it into a trilogy: The Songs of Enchantment (1995) and Infinite Riches (1998). This article examines how supernatural elements, in particular the West-African concept of abiku, affect both the content and the structure of Ben Okri's novel The Famished Road (1991); while also suggesting that Nigeria's transition to independence from colonial rule, as well as the ecological and economic consequences of colonialism are portrayed quite realistically, despite the novel's supernatural elements that make it a prominent example of a magical realist novel in the postcolonial world. Magical realism is often described as "the amalgamation of realism and fantasy" (Flores 1995, 112) as well as a literary mode that "facilitates the fusion, or coexistence, of possible worlds, spaces, systems that would be irreconcilable in other modes of fiction" (Zamora \& Faris 1995, 5-6). This article argues that The Famished Road creates this "coexistence" by using the supernatural elements of specific Yoruba and West African folklore within a Western literary form, namely the novel, as well as by registering the realistic and repetitive details of daily life in colonial Nigeria.

Although Ben Okri seems to be a good candidate for a list of what Timothy Brennan calls "cosmopolitan" authors, considering that he has studied in England, lives in London and writes in English, Okri's point of view remains decidedly African rather than metropolitan. (Brennan 1989). The Famished Road, Okri's best known work, draws attention through its keen focus on Nigeria. Kwame Anthony Appiah, for instance, in his review of the novel noted Okri's choice to write "as an African writer" despite his affiliation with England (Appiah 1992, 147). Ben Okri himself explains in an interview that he knows the slums and ghettos of Lagos where The Famished Road takes place and adds that "I'm probably quite rare amongst African writers in that sense. I was fortunate enough to have spent a substantial part of my life amongst the poor. So I could write about it, not as if I were a traveller, but as if I were one of them" (Guignery 2013, 22). This choice on Okri's part to write from an insider's point of view also affects the use of supernatural elements in his writing. Okri's magical realism differs greatly from other cosmopolitan writers who use this mode in the postcolonial world; he decidedly bases the central supernatural imagery of his novel on the West African myth of abiku, the spirit-child, and thus keeps it localized.

The Famished Road has a first-person narrator in Azaro, an abiku who lives on the outskirts of a big city with his parents. Azaro's stories consist mainly of his many travels and adventures in their poverty-stricken neighborhood, sometimes also partaking in adventures in the spirit world. Gifted with the ability to see another dimension of reality, Azaro spends most of his time wandering around his ghetto, walking in the near-by forest, and sitting in Madame Koto's bar, and all this time keenly perceiving what is happening in the neighborhood: the low income of his parents, the rivalry between the Party of the Poor and the Part of the Rich as the talks of independence increase, the poverty of the manual laborers like his parents and neighbors and the relative wealth of property owners like Madame Koto and their landlord, the deforestation of the forest and the building frenzy that accompanies the destruction of the trees.

The fact that Azaro is an abiku sets the tone of the novel both structurally and on the level of its supernatural content. Douglas McCabe explains that abiku literally means "one who is born, dies" and he also notes that "the compact 'born to die,' with its implication of a fated or 
deliberately planned death, has become the standard translation" (McCabe 2002, 46). The abiku phenomenon, is succinctly described by Ato Quayson as "a child in an unending cycle of births, deaths, and re-births," is quite popular within the Nigerian oral and literary tradition (Quayson 1997, 122). We learn from Quayson that this concept is widely believed in by three West African communities: Yoruba and Ijo (Ijaw) people share the word "abiku", while the Igbos refer to the spirit-children as "ogbanje" (122-3). On the other hand, the concept of abiku is already well-established in contemporary Nigerian literature by writers and poets such as Chinua Achebe, Wole Soyinka and J.P. Clark-Bekederemo who have already employed this phenomenon in their fiction and poetry.

Okri's choice in making the narrator/protagonist an abiku allows for the many recurrences and transformations in the novel as well as forming the base of the supernatural content in the novel. Chidi Maduka explains that abiku "goes through a continuous circle of birth and death as a result of a primeval oath... taken in the spirit world in the presence of the creator and binding on the living" which in turn makes the abiku "to live in a particular manner throughout his or her usually short span of life" (Maduka 1987, 18). We learn from Azaro very early in the novel that he breaks his promise to his spirit companions in the world of the unborn and "somewhere in the interspace between the spirit world and the Living" he chooses to stay (Okri 1991, 5). The reason why Azaro wants to stay this time around is not entirely clear, but he suggests "it may simply have been that I had grown tired of coming and going. It is terrible to forever remain in-between" (Okri 1991, 5). Azaro also informs us what happens to the spiritchildren that choose to stay:

Those of us lingered in the world, seduced by the annunciation of wonderful events went through life with beautiful and fated eyes, carrying within us the music of a lovely and tragic mythology. Our mouths utter obscure prophecies. Our minds are invaded by the images of the future. We are the strange ones, with half of our beings always in the spirit world (Okri 1991, 4).

Thus, early in the novel Okri establishes Azaro's extraordinary consciousness which makes it possible for him to perceive what is not visible to ordinary eyes. Furthermore, Azaro's broken promise and his refusal to go back to the spirit world by dying results in the endless efforts of his spirit companions to lure him back to the world by giving him hallucinations, and hence further complicating his sense of reality. Ben Okri confirms the centrality of Azaro's abiku nature to the novel:

The Famished Road is an integral work. Everything is contingent in the book. Its core is something impossible, the idea of the spirit-child. And the spirit-child is a poetic being... the poetry of the book comes out of the fact that this character is constantly seeing the world with a dual consciousness. What appears not to be real to us is real to him, and what appears to be real to us is not real to him. The poetry is such that if you miss the beat, you are out of that world. The source is the open consciousness of the narrator (Guignery 2013, 19) .

Throughout the novel, Azaro is usually the only witness to the supernatural happenings in his environment and he is alone in his adventures in the spirit world, which are for him mostly undesirable. Other characters like Madame Koto, the owner of a bar nearby who is rumored to be a witch and Azaro's abiku friend Ade also share some knowledge of the workings of the spirit world. On the other hand, Azaro's parents firmly believe in the existence of an unseen 
World, although they cannot experience it themselves. What seems to be unreal in this novel (and what is usually only visible to Azaro) seems to coexist with the real world that is perceived by everyone else. Azaro, most of the time, sees a parallel world full of grotesque hybrid creatures that have both human and animal qualities. This parallel world, sometimes seen while wide awake in the daylight and sometimes explored in dreams while sleeping, seems to coexist in Azaro's consciousness with this world of social injustices, poverty-stricken lives of the ghetto and the political instability of colonial Nigeria on the verge of independence.

The concept of abiku provides the ground for Okri to build the supernatural realities in the novel, and it is noteworthy that all the supernatural events seem consistent within the framework of the existence of the spirit world. In other words, the novel presents a worldview that encompasses the existence of the spirits (of both the ancestors and the unborn), a spirit-world of another or parallel dimension, and the ability of some people (abikus, herbalists, witches, and so on) to be in communication with these spirits. All supernatural events in the novel fall within this worldview; we do not encounter flying carpets, people suddenly ascending to sky or people with extraordinary abilities without an apparent connection to spirit world. As such, Okri's magical realism is presented more as a single reality, or a perception of reality, in which the supernatural is harmonious and widespread rather than a hybrid discourse caused by two different modes coming together. Ben Okri's ideas on African perceptions of reality seem to confirm this. He explains "In Africa myth transfigures reality. By myth, I also mean the rituals and beliefs of a people. All worldviews are superstitious. The world is not as we see it. The world is as we perceive it. Our perception makes our world. And Africa has its unique perceptions" (Guignery 2013, 18). As such it is only normal for the supernatural context of the novel to be strongly limited to the Yoruba oral tradition. John Mbiti in his African Religions and Philosophy explains the "spiritual universe is a unit with the physical, and these two intermingle and dovetail into each other so much that it is not easy, or even necessary, at times to draw the distinction or separate them" (Mbiti 1970, 97). In The Famished Road too, we can see this unified reality in Azaro's experiences that blur the distinctions between the real world and the spirit world, as well as the reality of the world and his dreams and hallucinations.

Ben Okri does not step out of the local oral tradition of the place he is depicting in the supernatural context of the novel. Nor does he posit Azaro's many supernatural experiences in contrast to a more scientific worldview, a more Western reality. In other words, he does not let Azaro's' experiences encountered a rationalistic worldview and be, in turn defined in opposition to such a view. Anjali Roy suggests the "African reality as portrayed in Okri's novel is not nonrational, non-scientific, or non-historical in a reversal of imperialistic readings of Africa, but looks at the world from a particular African point of view, the Yoruba, which is presented as a holistic, self-contained culture of totality independent of Europe's theories" (Roy 2000, 25). This is also of course a direct result of the limited presence of colonialism within the novel, which will be examined in detail later.

In The Famished Road, the cyclicality of the abiku has permeated into the narrative structure of the entire novel. Some of the events that repeat more than twice include: one of the family members (Azaro, Mum, or Dad) getting sick and lying unconscious for days while the other two waits on him/her and get help from a herbalist and perform rituals; disturbances created by the supporters of the Rich Party who give trouble to Azaro's parents both at their work places and in their neighborhood; Azaro wandering the roads aimlessly and encountering interesting scenes; Azaro getting lost and ending up in the forest; the landlord or other neighborhood men (the carpenter, the chair-hire man, the photographer) asking for the money Azaro's family owes them and in turn making the father angry; commotions inside Madame 
Koto's bar, or in her backyard, caused by either spirits or people, most of which are witnessed only by Azaro, and so on. Apart from these relatively major events in the novel, even the mundane habits of the family that take place in their small house (which is in fact a tiny room in a compound) is repeatedly depicted in detail: Mum comes from her hawking tired, and counts what little money she earned that day; she washes up, cooks dinner; the father comes home, likewise tired and angry; he also washes up, eats his dinner, sits in his three-legged chair and smokes cigarettes and drinks ogogoro after the dinner, sometimes sleeping in his chair; Azaro moves the center table, lays out his mat, sleeps and finds his parents gone when he wakes up. This pattern is repeated many times throughout the course of the novel with variations but always giving the utmost care to simple details, such as where the family members sleep each night, in the bed, on the mat under the table, or in the chair.

The decision of Okri to depict events that are repeated has result in comments that define the novel as "500 pages with only the barest semblance of a plot" (Appiah 1992,147) or suggest that "not much happens. What does transpire seems familiar and repetitive, as though one is living through many versions of the same dream or nightmare" (Cooper 1998, 68). Although these critics seem to acknowledge the underlying oral tradition in the novel, they seem critical of the repetitiveness, which in fact is one of the basic features of the oral tradition, particularly within the context of the cyclicality of the spirit-child. Walter Ong in his Orality and Literacy points out that the redundant and the copious nature of the oral narratives are indicative of "the public speaker's need to keep going while he is running through his mind what to say next" (Ong 2002, 40). Ong suggests that it may be disabling for the public speaker to hesitate, and so "it is better to repeat something, artfully if possible, rather than simply to stop speaking while fishing for the next idea" (Ong 2002, 40). This necessity on the storyteller's part to repeat in turn "[encourages] fluency, fulsomeness, volubility" in oral cultures (Ong 2002, 40). Of course, this novel is not an orally performed story, nor is Okri a public storyteller in need of repeating events while thinking of the next idea. However, I find Okri's repetitiveness within the novel indicative of an underlying aesthetics that mirrors this feature of the oral tradition.

The treatment of time in the novel completely abandons linearity for the sake of a cyclical understanding of the events. This can also be attributed to the abiku phenomenon and to the oral tradition and, alternately, we can assess this peculiar treatment of time in the novel as a mimetic representation of the concept of time in African societies. I find it helpful to turn to John Mbiti who suggests that the perception of time for Africans is different from that of Western societies where numerical calendars help to divide up time for people. Instead, Mbiti states the Africans traditionally use "phenomenon calendars" which emphasize the events taking place and their relation relative to each other: "The day, the month, the year, one's life time or human history, are all divided up or reckoned according to their specific events, for it is these that make them meaningful" (Mbiti 1970, 24). The Famished Road certainly supports this view as there are no references to days, weeks or months in its division of the time; we never know how much time has passed between the beginning and the end of the novel. The novel has no climactic storyline, nor does it have a specific event to mark the end of the novel. Okri stated in an interview that the novel "moves toward infinity" and talks of a "consciousness" that emerges in the book which "is already aware of other lives behind and in front and also of people actually living their futures in the present" (Wilkinson 1992, 83). Similarly, Mbiti also refers to the concept of infinity in African understanding of time in a similar statement to Okri's: "African peoples expect human history to continue forever...the days, months, seasons and years have no end, just as there is no end to the rhythm of birth, marriage, procreation and death" (Mbiti 1970, 31). The episodic structure of The Famished Road certainly reveals this rhythm by not 
prioritizing any event over any other.

Apart from giving the novel its supernatural context and lending its cyclical nature to the structure of the novel, the concept of abiku also works on an allegorical plane. The allegorical interpretation of the abiku phenomenon in The Famished Road cannot be ignored since towards the end of the novel Okri makes Azaro's friend Ade in his feverish condition come to a realization concerning the abiku aspect of their nation: "Our country is an abiku country. Like the spirit-child, it keeps coming and going. One day it will decide to remain. It will become strong. I won't see it' (Okri 1991, 478). Ade, unlike Azaro, has decided to give up the world of living to go back to the spirit world. So, while the endless cycle of life and birth can cause much sorrow and many problems, we learn that not all the abikus are the same. Azaro's willingness to stay this time is contrasted with the decision of Ade's to leave. Azaro, in one of the informative suggests that

Things that are not ready, not willing to be born or to become, things for which adequate preparations have not been made to sustain their momentous births, things that are not resolved, things bound up with failure and with fear of being, they all keep recurring, keep coming back, and in themselves partake of the spirit-child's condition. They keep coming and going till their time is right. History itself fully demonstrates how things of the world partake of the condition of the spirit-child (Okri 1991, 487).

Azaro states this towards the end of the novel, when the preparations for the much-awaited political rally are under way and talk of independence has increased the rivalry between the political parties. These references to the allegorical aspect of the abiku phenomenon in the novel have been noted by most critics including Henry Louis Gates and Kwame Anthony Appiah. Gates, referencing Soyinka's poetry and the cyclical imprisonment of the abiku suggests that, "one can scarcely imagine a more suitable metaphor for the frustrated hopes of African independence and democracy" (Gates 1992). However, he also notes the difference in Okri's use of the concept: "In his hands, the enigmatic, mythical figure of the abiku sustains enormous thematic and narrative freight, as we follow the progress of a being who wishes to break his destined cycle of death and rebirth" (Gates 1992). I agree with Gates particularly in considering Azaro's continued efforts to stay in this world and fight the spirits who try to allure him into returning. Appiah, on the other hand, does not appreciate Okri's impulse to "[decode] one level of his own allegory" and suggests that Okri possibly offers this allegorical explanation to give "moral weight" to the tale of the spirit world, which Appiah suspects is offered "in part a concession to readers who do not put much stock in spirits" (Appiah 1992, 147). While Appiah might be correct in his assessment, I think the narrative allows for both literal and metaphorical meanings to be registered without one canceling out the other.

The abiku phenomenon, as we have seen, dominates the novel not only because the narrator/protagonist is a spirit-child but also because it has a hold on the narrative structure of the novel; it demarcates the supernatural content of the novel, and provides the main metaphor of the novel. On the other hand, despite this heavy presence of the concept of spirit-child in the novel, it is entirely possible to read The Famished Road as a realistic narrative. This does not mean that the supernatural events should be isolated from the realistic narrative, but that within the extraordinary narrative the realistic details of the contemporary life in Nigeria prevail.

The Famished Road, apart from being widely accepted as an example of "magical realism," has also been given many labels including "spiritual realism" (Appiah 1992, 146), "sacred 
realism" (Mathuray 2009, 115), "animist realism" (Quayson 1997, 148), "shamanic realism" (Oliva 1999, 174) and "local realism" (James 2013, 267). The significance of this effort by many critics to re-label the novel can be understood as being a direct result of their own dissatisfactions with the term "magical realism." And the fact the first part of this term "magical" keeps changing, while the second part of the term, "realism" remains, demonstrates the firmness of the realist conventions in Okri's fiction as well as his break from the celebrated examples of magical realism in terms of the supernatural content of the novel. Both Appiah and Gates refer to Latin American writers such as Gabriel Garcia Marquez to note their difference from Okri's kind of supernatural realism. I argue that this is a result of the conceived assumption that magical realism is limited to Latin American writers, and the fact that a definition of magical realism that encourages local differences in its employment of supernatural has not become widespread. The use of the adjectives "sacred," "spiritual," "animist," "shamanic" and "local" to define Okri's "realism" suggests an organic view of reality inherent in the novel which also encompasses the supernatural, rather than invoking a magical realist text that seems to bring two different modes of realism and the fantastic. This is certainly a result of Okri's adherence to the oral tradition and to Yoruba folklore in constructing the supernatural context of his novel. As such, Okri's supernatural narrative supports my definition of magical realism as the narrative mode of a single reality that has already the supernatural in it, rather than a mixed form of two different worldviews or narrative modes.

Azaro's small neighborhood with the nearby forest and the road demarcating it remains unnamed in the novel as well as the nearby big city (widely assumed to be Lagos). This results in various comments from critics such as Vanessa Guignery's that "The homelands of The Famished Road are certainly 'imaginary' and invisible as the novel is not explicitly bound to a specific geographical and historical place or nation" (Guignery 2013, 13). We have already discussed the allegorical portrayal of Azaro as an abiku. And this lack of certainty as to the location of the story might seem to add to metaphorical readings of this small community, making it any country in Africa, or any emerging postcolonial nation in the world. However, not all critics agree with Guignery's assumption that the location of the novel is not ascertainable geographically. Erin James, examining the "bioregionalism" of the The Famished Road, suggests that it is possible to determine a specific location for the novel by examining the meteorological events and the species described in the novel. James points out that despite the abundance of fantastic elements in the text, the novel retains a sense of a local environment which she calls "local realism" (James 2013, 267). After examining the depictions of the meteorological events in the novel which she finds realistically described and "certainly not fantastic" she also notes the species mentioned in the novel:

The novel features over one hundred and thirty species of flora and fauna, ranging from those familiar to a Western reader-chickens, dogs, and tomatoes-to those more easily associated with a Nigerian settingflame-lily, baobab, and yam. The flora Azaro finds as he explores the forest that borders his ghetto, such as mistletoe and palm, obeche, iroko, rubber, and mahogany, help to localize The Famished Road to tropical Africa. The fauna Okri mentions, including the antelope and the duiker, help to localize the text even further to the Yoruba home of the southwest part of Nigeria's rainforest, which is particularly known for these two species, both endangered by hunting pressure (Guignery 2013, 269).

This point examined in such detail by James is important in grounding the novel realistically and firmly in our physical world. As the first person narration of Azaro does not include specific 
dates and place names and does not address historical events directly, it is important to keep track of what makes Azaro's story as equally real as it is fantastic. James's bioregional reading of the novel certainly helps us do that.

As we can perceive in many other magical realist novels (Salman Rushdie's Midnight's Children and Gabriel Garcia Marquez's One Hundred Years of Solitude being prominent examples) The Famished Road registers the transformation and transition of a country at a critical time: in this novel, we witness a story of transition from colonialism to independence told through the eyes of a child from a working class family struggling with poverty. The geographical location addressed in the novel is a relatively small area, limited to the neighborhood where Azaro and his family live and journeys on-foot taken by Azaro to different parts of the city on "endless" roads. This limited geographical location renders the change this transformation and transition brings even more clearly into focus:

Steadily, over days and months, the paths had been widening. Bushes were being burnt, tall grasses cleared, tree stumps uprooted. The area was changing. Places that were thick with bush and low trees were now becoming open spaces of soft river-sand. In the distance I could hear the sounds of dredging, of engines, of road builders, forest clearers, and workmen chanting as they strained their muscles. Each day the area seemed different. Houses appeared where parts of the forest had been. Places where children used to play and hide were now full of sand piles and rutted with house foundations. There were signboards on trees. The world was changing and I went on wandering as if everything would always be the same (Okri 1991, 104).

This passage clearly focuses on the change that is happening in the nearby area, so immediately affecting Azaro's life. The forest and the trees are replaced by roads and houses; the children's playground is taken from them. The narrative also puts emphasis on the continuity of the construction work with the sounds of machinery and workers permeating Azaro's life and reminding of its presence even when he cannot see them. In another of his wanderings, where he ends up in the city away from his ghetto, Azaro depicts the even more striking changes that reveal the extent of the uneven development that the country is passing through:

The road was endless. One road led to a thousand others, which in turn fed into paths, which fed into dirt tracks, which became streets, which ended in avenues and cul-de-sacs. All around, a new world was being erected amidst the old. Skyscrapers stood high and inscrutable beside huts and zinc abodes. Bridges were being built; flyovers, half-finished, were like passageways into the air, or like future visions of a time when cars would be able to fly. Roads, half-constructed, were crowded with heavy machinery (Okri 1991,113).

This passage reveals much about the process of development in the building sector in an urban environment, showing us the progress of "the road" through its many stages and variations, as well as contrasting the new and the old, the skyscrapers and the huts. It is noteworthy that Okri describes these developments as "half-finished" and "half-constructed" emphasizing a transitional period for the country.

One of the biggest transformations, closely related to these building developments and the one which we are reminded of continually throughout the novel, is the slow disappearance of the forest near Azaro's ghetto. In the novel, the forest is depicted as a point of convergence for 
the spirits; one of the places where Azaro experiences most of his adventures with the spirit world; a source of resources in the poverty-stricken neighborhood and a much needed refuge for Azaro and other characters who are affiliated with the spirit world. The importance of the forest in the novel is also apparent in Erin James's bioregional reading, as we have seen above. The fact that many of the species that help James to define the location of the novel came from the forest reveals much about the dire results of this deforestation. The forest becomes the source that enables the reader to pinpoint Azaro's neighborhood on map, to distinguish it from any other ghetto in another corner of the world. As James points out, we rely on the duiker, the iroko and the obeche to give to the novel a sense of individuality; the forest possesses the capacity to define and the destruction of the forest, amongst other things, means the area loses its particularity.

Azaro mentions the forest for the first time early in the novel when he is abducted by a group of women after he became separated from his mother on the night of the riots. When the women and Azaro run through the forest, he realizes that

The forest swarmed with unearthly beings. It was like an overcrowded marketplace. Many of them had red lights in their eyes, wisps of saffron smoke came out of their ears, and gentle green fires burned on their heads. Some were tall, others were short; some were wide, others were thin. They moved slowly. They were so numerous that they interpenetrated one another. The women ran through these beings without any fear (Okri 1991, 12).

In this first encounter with the forest in the novel, Azaro realizes the over population of the forest with these spirits, as well as implying that he alone saw these beings, as they do not stir any fear in the women. The second time Azaro visits the forest is after he gets away from the women and begins watching a marketplace while wandering around the city. Before his travels take him to the forest again, Azaro encounters spirits in the marketplace: "That was the first time I realised it wasn't just humans who came to the marketplaces of the world. Spirits and other beings come there too. They buy and sell, browse and investigate. They wander amongst the fruits of the earth and sea" (Okri 1991, 16). When he follows these spirits from the marketplace in his curiosity, Azaro sees that a clearing in the forest is their departure point from this world where they say their farewells and go their own way. So, in his first two experiences in the forest, Azaro already establishes a firm connection between spirits and the forest. Furthermore, in his second excursion into the forest, Azaro notices the disturbing reality going on in the forest:

The clearing was the beginning of an expressway. Building companies had levelled the trees. In places the earth was red. We passed a tree that had been felled. Red liquid dripped from its stump as if the tree had been a murdered giant whose blood wouldn't stop flowing (Okri 1991,16).

Encountering the felled trees for the first time, Azaro compares in powerful imagery the destruction of the trees to murder. As James also notes, in this personifying depiction of the trees, trees turn into giants and the sap flowing from the stump of the tree represents blood (James 2013, 271). Azaro's depiction of the scene not only emphasizes the violent nature of what is being done, but he also exposes the culprit: the building companies. This awareness on Azaro's part of the reason behind the destruction of the forest sheds light on the ongoing colonial and postcolonial development projects of Nigeria.

After establishing that the forest is a place for the unearthly beings as well as the humans 
and animals of this world, Azaro's next adventure in the forest shows us the importance of the forest as a food resource for the poor. When Azaro makes it to home safe and sound after his disappearance during the riots, his parents throw a celebration for which the father hunts down a boar to serve the guests. Although it is impossible for them to afford a party, the parents go through it because the herbalist who advised them on the whereabouts of Azaro urged them to do so when he is found. The forest provides them with the boar which they couldn't otherwise afford and it becomes the main dish of the party, attended by the whole community for whom it turns into a feast. But we are immediately reminded that this is not something that will continue for a long time. During their visit to the forest to hunt down the boar, Azaro's father confirms the frightening aspect of what Azaro has earlier witnessed: “... sooner than you think there won't be one tree standing. There will be no forest left at all. And there will be wretched houses all over the place. This is where the poor people will live" (Okri 1991, 34). The building frenzy of the developing world replaces the forests with the slums that will be home to the newcomers to the city. As the novel proceeds, the father's prophecy comes close to realization. Azaro frequently notes the violent fate of the trees:

It took longer to get far into the forest. It seemed that the trees, feeling that they were losing the argument with human beings, had simply walked deeper into the forest. The deeper in I went, the more I noticed the difference. The grounds were covered in white sand. Piles of brick and cement were everywhere (Okri 1991,104).

I got to the edge of the forest and heard trees groaning as they crashed down on their neighbours. I listened to trees being felled deep in the forest and heard the steady rhythms of axes on hard, living wood (Okri 1991,137).

In the afternoons the forest wasn't frightening, though I often heard strange drums and singing and trees groaning before they fell. I heard the axes and drills in the distances. And every day the forest thinned a little. The trees I got to know so well were cut down and only their stumps, dripping sap, remained... Sometimes I watched the men felling trees and sometimes the companies building roads (Okri 1991,143).

I became certain that the whole forest was moving... The trees were running away from human habitation (Okri 1991, 243).

Time moved slower than the hot air. In the distance, from the forest, came the unending crack of axes on trees (Okri 1991, 270).

These quotations uttered quite casually within the flow of Azaro's daily movements firmly remind us of the violence that the trees suffer, while maintaining the personification of the trees, through mentioning their "groaning" and their "neighbours", or suggesting that they walk away to escape from the humans and their horrible destruction. We should note that the violence against the forest shadows the many instances of violence in the ghetto, mostly inflicted by the political thugs of the new parties, and including the domestic violence of Azaro's father towards the mother of Azaro and Azaro. As such, this violence becomes ordinary, a daily event throughout the novel, one of many repeated sequences. With the environmental violence directed at the forest, though, it is not easy to see the direct results right away. Rob Nixon 
describes this kind of environmental violence as "slow violence" that "is neither spectacular nor instantaneous but instead is incremental, as its calamitous repercussions are postponed across a range of temporal scales" (Nixon 2011, 257). Ben Okri's repeated depiction of deforestation spread throughout the course of the novel exemplify Nixon's description of "slow violence" and they depict a very real problem of contemporary Nigeria facing many large environmental problems at the hands of colonialism and global capitalism. Apart from the deadly results of the oil extraction processes conducted around the Niger Delta, the other main environmental problem of Nigeria today is deforestation, which in turn leads towards desertification and climate warming. A report by The Food and Agriculture Organization of the United Nations (FAO) states that between the years 2000 and 2005, Nigeria had the worst deforestation rates in the world, having lost 55.7 percent of its primary forests during that breif period of time (Butler 2005). In accord with Nixon's definition of "slow violence," the real devastating consequences of the destruction of Nigerian forests that began in the colonial period as is depicted in The Famished Road was thoroughly understood decades later.

Jonathan Highfield notes that there is a direct connection in the novels between deforestation and the lack of food. He suggests that although deforestation usually means more space for agriculture, the situation has been different in West Africa because "a great deal of agriculture in West Africa was agroforestry, in which cultivated crops were grown alongside a variety of tree species" (Highfield 2011, 144). Referencing Fanon's The Wretched of the Earth, Highfield suggests that exercising "control over food and food production is an integral part of the process of decolonization" (Highfield 2011, 141). Highfield continues:

Food sovereignty, then, is one of the defining principles of true liberation in a Fanonian sense, and food sovereignty in West Africa is inextricably bound up with forest use and protection because of the long history of agroforestry across the region. In forest regions communities have long and deep relationships to the forest that predate the colonial and neocolonial eras. Those relationships vary widely, but most local communities across West Africa lost significant control over forest resource use in the late colonial period, a situation that continued after independence (Highfield 2011, 152).

We have already seen that the forest meant resources, particularly for the poor people of the ghetto. What Highfield suggests above sheds light on the importance of the forest for the local communities and how their destruction affects these people. Drawing our attention to the roadbuilding frenzy which is depicted as the main reason for the destruction of the forests, Highfield also suggests that "The famished road, then, is a representation of global capitalism. The road eats without discrimination, devouring whole communities in its mission to feed an insatiable external market" (Highfield 2011, 146).

However, The Famished Road does not explicitly place the blame upon colonial rule. In Infinite Riches, the last book of the trilogy, Okri seems more intent on holding colonial rule responsible. The road which nears its completion and the construction of which has been responsible for this deforestation, is described as such: "It was indeed a splendid road. It had been built by the natives, supervised by the Governor - General. He dreamt that on this beautiful road all Africa's wealth, its gold and diamonds and diverse mineral resources, its food, its energies, its labors, its intelligence would be transported to his land, to enrich the lives of his people across the green ocean" (Okri 1998, 236). In The Famished Road, Azaro only implicitly mentions the colonial administration or foreign companies as the reason behind the 
degradation of his environment. He usually mentions "builders" or "workers" only fleetingly when he describes a scene of tree-cutting or construction. Only in one instance does Azaro refer to an authority figure at the construction site: "white man". This also happens to be the first time that Azaro sees a white man in his life. The white man, he learns from other children, is bringing electricity to their neighborhood. In the short time that Azaro observes him the man kills a lizard by stepping on it and commands the workers to dispose of its corpse. Later in the novel, we learn from Azaro's father (as Azaro does) that lizards should be respected and that they can protect one and warn of imminent dangers. The white man does not know this and the lizard dies at his feet. When the white man orders the workers to chase the children away, Azaro "conceived a terrible dislike for the white man" (Okri 1991, 278). The next time we see the same white man is a few pages later, in the first downpour of the rainy season near the pit that has been excavated for the sand to be used in the constructions. The rain and wind has had a destructive effect on the construction sites and recently built roads. "Suddenly the path turned into a ditch. The earth moved. Floodwaters from the forest poured underneath us" (Okri 1991, 288). Azaro is saved by clinging to the stump of a felled tree but he witnesses the white man as he "slid down slowly into the pit, as a stream of water washed him away" (Okri 1991, 288). The man does not surface and a few workers who go into the pit to save the white man do not come back, either. Azaro simply states that "the pit that had helped create the road had swallowed all of them" (Okri 1991, 288). This whole passage is told as if the natural forces of the wind, rain and the "floodwaters from the forest" came together to destroy, not only the road that has caused so many trees to be cut down but also those who are responsible for it. This event can be compared to a similar event that occurs in the sequel, Songs of Enchantment. When Azaro and his father get caught in heavy rain inside the forest and floodwater threatens their lives, Azaro's father is barely saved from falling into the pit by holding on to the roots of a tree. Needless to say, there was no tree for the white man to hold on to. The white man, having killed the lizard which came to warn him and having cut the tree that might have saved him, is killed by the natural forces in the very pit that made the road and his work possible.

Apart from this scene in which the white man is killed by the natural forces, the colonial presence or any reference to it is simply lacking in the novel. It has been already mentioned that Okri's use of the supernatural elements is unequivocally based upon the Yoruba oral tradition and philosophy and is represented as an integral worldview rather than a collection of various supernatural events scattered through the text. Apart from adhering to the myths, rituals and beliefs of the society he is depicting, Okri also manages to create this worldview by circumventing any colonial encounter that would possibly make Azaro aware of a different perception from his own, one that denies his worldview. The lack of a colonial presence in the novel was later acknowledged by Okri who suggests in an interview that "while it is true that everybody in a place like that could be affected by the colonial presence, isn't it just quite possible that within it there may be people who are living their lives almost completely unaware that it was happening?" (Wilkinson 1992, 86). Okri clearly opts for a deliberate exclusion of colonial administration from the narrative. This is in part due to his belief that cultural colonization is far more detrimental for a society's well-being than the invasion of the land and infrastructure:

... there has been too much attribution of power to the effect of colonialism on our consciousness. Too much has been given to it. We've looked too much in that direction and have forgotten about our own aesthetic frames. Even though that was there and took place and invaded the social structure, it's quite possible that it didn't invade our spiritual 
and aesthetic and mythic internal structures, the way in which we perceive the world... a true invasion takes place not when a society has been taken over by another society in terms of its infrastructure, but in terms of its mind and its dreams and its myths, and its perceptions of reality. If the perception of reality has not been fundamentally, internally altered, then the experience itself is just transitional. There are certain areas of the African consciousness which will remain inviolate. Because the world-view it is that makes a people survive (Wilkinson 1992, 86).

Clearly, Okri intends his aesthetic structure in the novel to reflect this view. And for Azaro to have his "inviolate" consciousness, the narrative has to shun the colonial encounter, including the depiction of school system under colonial rule. Accordingly, the only colonial encounter Azaro experiences in the novel is with the white man on the construction site, which ends in the white man's death at the hands of natural forces.

Okri's language in the above quote can be interpreted as the language of "myth and conservation, of pure and inviolate African ways of seeing the world" and as "diametrically opposed to the hybrid, to change" which is made possible by stories "lifted out of historical context" (Cooper 1998, 90). Or, one might suggest, as Margaret Cezair-Thompson does, the lack of a colonial presence makes the novel "an example of decolonized fiction", in that it urges the critics "to look beyond the postcolonial and to recognize a new direction in African literature, one which, while recognizing historic situations, is not limited to a historic perspective" (Cezair-Thompson 1996, 34). Keeping in mind that this novel is narrated through a child's eyes, a consequence of which is the lack of articulate arguments concerning specific historical conditions, I argue that the lack of a colonial presence does not necessarily mean that Okri ignores the historical reality and the consequences of colonialism but chose instead to focus upon the struggle of these poor people, the working class families, against the forces which will continue to oppress them whether they live under colonial rule, or they elect their own governments in a free country. There is a political context in the novel that slowly evolves from people resisting the police during a riot by beating and tearing "their colonial uniforms" (Okri 1991, 10), to getting excited about the new political parties as they are seen as the harbingers of the coming independence, and then to the disillusionment towards the parties as their corruptness becomes clear, evidenced in the carpenter's repeated statement that "they are all corrupt" (Okri 1991, 211). This results in disillusionment with independence even before it actually arrives: Azaro hears people in the marketplace commenting that "This Independence has brought only trouble" (Okri 1991, 169) or his own mother who refers to it as "all the Independence trouble" (Okri 1991, 483). Their lack of enthusiasm echoes what Joseph D'Costa, one of Salman Rushdie's minor characters in Midnight's Children, has had to say about Indian independence: "This independence is for the rich only; the poor are being made to kill each other like flies... Riots riots, poor against poor. It's in the wind" (Rushdie 2006, 117).

In part caused by the absence of a colonial presence and worldview, there is also very limited content in the novel to which one could apply the widespread concepts of postcolonial theory, such as migrancy, cosmopolitanism, and hybridity. The only mention of any sense of migrancy is given only at the beginning, when Azaro defines his birth as an "exile" from the spirit world. As we have already stated, the novel is limited in its geographical and historical scope, and quite contained culturally within the framework of Yoruba religion and philosophy. The few examples that might suggest the cosmopolitan nature of Lagos are only mentioned in passing when Azaro hears people on the road speaking in tongues he does not understand, or in the fact that his friend's Ade's family is Muslim. On the other hand, there are no visible binary 
oppositions at contrast with each other which would eventually be resolved by meeting those oppositions in a middle ground allowing for hybridity. The only revealed interspace in the novel is the one Azaro holds between the spirit world and our world, and as such, it lies entirely outside the colonial cultural paradigms.

The Famished Road registers a transition but rarely addresses hybrid cultural models; the hybridity Okri engages with is a structural one that shapes the narrative. Okri states that "One of the strongest impulses which made me write The Famished Road is that I got tired of the traditional artifices and realism of the novel. I wanted to cut all that, going directly to the point in a different way, but still in the form of a novel" (Deandrea 2002, 47). I argue that his insistence in the novel form to tell his stories that draw much from Yoruba and West African folklore is what grounds him in the literary tradition of magical realism. The Famished Road, by borrowing its theme and structure from the abiku phenomenon of West African culture, registers the changes and the transition in a temporally and spatially specific ghetto of Lagos, and the cyclical nature of the plot with many events repeated in the course of the novel renders the depiction of transformation slow and hidden in the details of this poetic narrative. Such an example is this conversation between Madame Koto and Azaro, which transpires after they witness a man taken into the forest by three thugs to be probably killed:

'If you misbehave the same thing will happen to you.'

'What?'

'The forest will swallow you.'

'Then I will become a tree,' I said.

'Then they will cut you down because of a road.'

'Then I will turn into the road.'

'Cars will ride on you, cows will shit on you, people will perform sacrifices on your face.'

'And I will cry at night. And then people will remember the forest.' (Okri 1991, 219)

This conversation is able to capture the essence of the cyclical structure of the novel as well as reminding us the violent transition of the forest into the road, at the same time noting that there is no end to the cycle and transitions because "people will remember the forest." 


\section{REFERENCES}

Appiah K. A. (1992). "Spiritual Realism". The Nation 255/4 (1992) 146-48.

Brennan T. (1989). Salman Rushdie and the Third World. London 1992.

Butler R. A. (2005). "Nigeria has the Worst Deforestation Rate, FAO Revises Figures". Source: http://news.mongabay.com/2005/1117-forests.html\#J1bs3UshITlKkcrb.99. Accessed: 12 March 2013.

Cezair-Thompson M. (1996). "Beyond the Postcolonial Novel: Ben Okri's The Famished Road and its 'Abiku' Traveller". The Journal of Commonwealth Literature 31/2 (1996) 33-45.

Cooper B. (1998). Magical Realism in West African Fiction: Seeing with a Third Eye. London 1998.

Deandrea P. (2002). Fertile Crossings: Metamorphoses of Genre in Anglophone West African Literature. Amsterdam and New York 2002.

Flores A. (1995). "Magical Realism in Spanish American Fiction". Eds. L. P. Zamora \& W. Faris. Magical Realism: Theory, History, Community (1995) 109-17. Durham, NC.

Gates H. L. Jr. (1992). "Between the Living and the Unborn". By B. Crider, The New York Times Book Review (1992) 3-20.

Guignery V. (2013). The Famished Road: Ben Okri’s Imaginary Homelands. UK 2013.

Highfield J. (2011). "No Longer Praying on Borrowed Wine: Agroforestry and Food Sovereignty in Ben Okri's Famished Road Trilogy". Eds. G. Myers \& B. Caminero-Santangelo. Environment at the Margins: Literary and Environmental Studies in Africa (2011) 141-158. Athens.

James E. (2012). "Bioregionalism, Postcolonial Literatures, and Ben Okri's The Famished Road". Eds. C. Glotfelty \& T. Lynch. The Bioregional Imagination: Literature, Ecology, and Place (2012) 263277. Athens.

Maduka C. T. (1987). "African Religious Beliefs in Literary Imagination: Ogbanje and Abiku in Chinua Achebe, J. P. Clark and Wole Soyinka". Journal of Commonwealth Literature 22/1 (1987) 17-30.

Mathuray M. (2009). On the Sacred in African Literature: Old Gods and New Worlds. Basingstoke 2009.

Mbiti J. (1970). African Religions and Philosophy. London 1970.

McCabe D. (2002). "Histories of Errancy: Oral Yoruba Abiku Texts and Soyinka's 'Abiku". Research in African Literatures 33/1 (2002) 45-74.

Nixon R. (2011). "Slow Violence, Gender, and the Environmentalism of the Poor". Eds. G. Myers \& B. Caminero-Santangelo. Environment at the Margins: Literary and Environmental Studies in Africa (2011) 257-285. Athens.

Okri B. (1991). The Famished Road. New York 1991.

Okri B. (1993). Songs of Enchantment. London 1993.

Okri B. (1998). Infinite Riches. London 1998.

Oliva R. (1999). "Re-Dreaming the World: Ben Okri's Shamanic Realism". Eds. E. Linguanti \& Francesco Casotti. Coterminous Worlds: Magical Realism and Contemporary Post-Colonial Literature in English (1999) 171-196. Amsterdam.

Ong W. J. (2002). Orality and Literacy: The Technologizing of the Word. London and New York 2002.

Quayson A. (1997). Strategic Transformations in Nigerian Writing. Bloomington 1997.

Roy A. (2000). "Post-Modern or Post-Colonial? Magic Realism in Okri's The Famished Road". Eds. D. Gover, J. Conteh-Morgan \& J. Bryce. The Post-Colonial Condition of African Literature (2000) 2339. Trenton.

Rushdie S. (2006). Midnight's Children: A Novel. New York 2006.

Wilkinson J. (1992). Talking with African Writers: Interviews with African Poets, Playwrights and Novelists. London 1992.

Zamora L. P. \& Faris W. B. (1995). Magical Realism: Theory, History, Community. Durham, NC 1995. 
